\title{
DECLARATIONS AND THE INDONESIAN CONSTITUTION ON RELIGIOUS FREEDOM
}

\author{
Alexius Andang L. Binawan \\ Driyarkara School of Philosophy, Jakarta, Indonesia
}

\begin{abstract}
One of controversial issues in Indonesia regarding buman rights is concerning religious freedom. There were two contradict opinions on the issue, i.e. those who preferred Indonesia as an Islamic state, with a consequence that there is only very limited religious freedom and those who preferred secular state with a wider religious freedom. Though finally Indonesia adopted Pancasila (five pillars) as the state ideology, as a mid-way between the two, final agreement on the problem is from being finalised as debates are still carried out. This paper is aimed at analysing how and where the 'pendulum' is swinging between two contrasting views since Indonesia has signed both the International Covenant on Civil and Political Rights and also the Cairo Declaration of Human Rights. I argue that during the New Order Indonesia, the pendulum on religious freedom swung closer to Islamic view.
\end{abstract}

[Salah satu isu terkait Hak. Asasi Manusia di Indonesia adalah mengenai kebebasan agama. Setidaknya ada dua cara pandangyang saling bertentangan, yaitu (1) yang menghendaki bentuk negara Islam, konsekuensinya adalah kebebasan agama sangatlah terbatas, dan (2) yang menginginkan negara sekuler yang mengindikasikan kebebasan agama lebih luas. Indonesia mengadopsi Pancasila sebagai ideologi negara dan sebagai jalan tengah antara kubu negara Islam dan sekuler, namun perdebatan mengenai bentuk negara tersebut terus saja bergulir. Artikel ini menganalisis bagaimana dan ke mana 'pendulum' bergerak di antara dua pandangan yang saling bertentangan di atas. Semasa Orde Baru, pendulum tersebut condong ke kubu Islam.] 
Keywords: human rights, Pancasila, religious freedom

\section{A. Introduction}

The dispute concerning human rights in the international sphere is still going on. There are at least three views involved in this dispute: the universalist; the culturally relativist, and Islamic. This study will not explore this dispute, but it will examine the encounter between those three views in Indonesian policies on human rights, especially during the New Order era (the Soeharto's presidency, 1966-1998), with a particular attention to the official policies concerning religious freedom. To do so, the essay limits the discussion through examining the Indonesian policies on human rights with regards to religious freedom. This topic is worth noting as currently growing Islamic revivalism, especially of fundamentalist ideas that advocate the implementation of shari' ah (Islamic laws) in Indonesia. In addition, the periodical limitation on the discussion mainly on the New Order Indonesia (1966-1998) is significant as I argue that many legal products of the New Order are still in force and to some extent have raised socio-political problems.

As far as the state ideology concerned, Indonesia is a nonconfessional state. With Pancasila (five pillars, i.e. belief in one Almighty God, humanitarianism, nationalism, democracy guided by consensus and social justice) as its national ideology, Indonesia is a 'religious' state, in the sense that it recognises religion as an important factor in the society. Though Islam is the majority with about $88 \%$ of the population, Indonesia is not an Islamic state in the strict sense. In other words, Indonesia has only been half-hearted in applying international standards of human rights as well as Islamic standards on human rights.

In addition, Indonesia tries to bridge the forementioned three views on human rights. Since these three seem to oppose each other, it is interesting to understand how the Indonesian state deals with them. First of all, Indonesia is an active member of the United Nations (UN). Therefore, Indonesia is morally obliged to follow the Universal Declaration of Human Rights (UDHR). However, within the international discourse on human rights, for the first four decades of its independence, Indonesia seemed to be hesitant to adopt the UDHR as its legal reference. There 
were a lot of philosophical and political reasons behind, ${ }^{1}$ but nevertheless some principles of human rights have been stipulated in Pancasila and in the 1945 Constitution, especially in the articles 27, 28, 29, 30, 31 and 33. However, it was only in 1993 that the government established the National Commission on Human Rights (Komisi Nasional Hak Asasi Manusia/Komnas HAM) through the Decree of the President of the Republic of Indonesia No. 50/1993, following the recommendation of a workshop on human rights held by The Department of Foreign Affairs (Kementrian Luar Negeri) of the Republic of Indonesia and the UN on 22 January 1991. It is stated in that decree that one of its tasks is to examine various $\mathrm{UN}$ instruments on human rights with a view to presenting suggestions regarding the possibility of accession to or ratification of these instruments.

Concerning the human rights issue, it is necessary to notice that in the early era of independence, Indonesia had tried to include some human rights articles in its constitution. The 1949 and the 1950 Provisional Constitutions mention some stipulations on human rights inspired by the UDHR. However, since 1959, the President reinstated the 1945 Constitution and consequently those stipulations mentioned in the 1949 \& 1950 constitutions had no effect. There was another effort in 1968 to adapt the human rights principles of UDHR to Indonesian society. An ad-hoc committee of the Provisional People's Consultative Assembly dealing with human rights issues was established. This committee had drafted a document so called Piagam Hak-hak Asasi Manusia dan Hak-hak serta Kewajiban Warga Negara (the Charter of Human Rights and Citizens' Rights and Duties). There were many human rights principles mentioned in that document, but unfortunately the Provisional People's Consultative Assembly (Majelis Permusyawaratan Rakyat Sementara/MPRS) failed

${ }^{1}$ Ali Alatas, the former Indonesian minister of foreign affairs, stated that Indonesia is firmly committed to the UDHR, but he urged for the importance of international co-operation and mutual respect concerning the application of the UDHR, based on the uniqueness of each states. See Ali Alatas, "An Indonesian View on Human Rights," in Barend van der Heijden and Bahia Tahzib-Lie, Reflections on the Universal Declaration of Human Rights. A Fiftieth Anniversary Anthology (The Hague: Martinus Nijhoff Publishers, 1998), pp. 21-26. 
to adopt it. ${ }^{2}$

Indeed, though Indonesia had joined the UN in 28 September $1950,{ }^{3}$ by 1998, it had yet to ratify the International Covenant on Economic, Social and Cultural Rights (ICESCR) and the International Convention on Civil and Political Rights (ICCPR). There are only five international conventions, which are ratified or acceded by Indonesia. Those are the Convention on the Elimination of All Forms of Discrimination against Women, ${ }^{4}$ the Convention against Torture and Other Cruel, Inhuman or Degrading Treatment or Punishment, ${ }^{5}$ the International Convention against Apartheid in Sports, ${ }^{6}$ the Convention on the Rights of the Child ${ }^{7}$ and the International Convention on the Elimination of All Forms of Racial Discrimination. ${ }^{8}$ In this case, Indonesia is consistent with its view on the UDHR as reflected in the Bangkok Declaration (1993), in the Kuala Lumpur Declaration (October 1993), and also in the Cairo Declaration on Human Rights in Islam which Indonesia signed. This is also part of the reasons why Indonesia still has some reservations to the above ratified and accessed conventions.

On the other hand, Indonesia has been a member of the Association of South East Asian Nations (ASEAN) and also to the Organisation of the Islamic Conference (OIC). Indonesia signed the Bangkok Declaration of Human Rights on 2 April 1993 and the Kuala

${ }^{2}$ See Todung Mulya Lubis, In Search of Human Rights (Jakarta: Gramedia Pustaka Utama and SPES Foundation, 1993), pp. 130-139.

${ }^{3}$ Indonesia withdrew from the UN on 20 January 1965, and joined again on 19 September 1966.

${ }^{4}$ Adopted by the General Assembly of the United Nations on 18 December 1979, entered into force on 3 September 1981, ratified by Indonesia on 29 Jul 1980/13 Sep 1984 (entrance into force).

${ }^{5}$ Adopted by the General Assembly of the United Nations on 10 December 1984, entered into force on 26 June 1987, ratified by Indonesia on 23 Oct 1985/28 Oct 1998.

${ }^{6}$ Adopted by the General Assembly of the United Nations on 10 December 1985, entered into force on 3 April 1988, ratified by Indonesia on 16 May 1986/23 Jul 1993.

${ }^{7}$ Adopted by the General Assembly of the United Nations on 20 November 1989, entered into force on 2 September 1990, ratified by Indonesia 26 Jan 1990/5 Sep 1990.

${ }^{8}$ Opened for signature at New York on 7 March 1966, entered into force on 4 January 1969, accessed by Indonesia on 25 June 1999. 
Lumpur Declaration on Human Rights in October 1993. As an active member, and even one of the founding nations, of the OIC, Indonesia participated in signing the Cairo Declaration of Islamic Human Rights in 1990. While the first-two declarations emphasise the importance of the cultural context of Asian values, the Cairo Declaration emphasises the supremacy of shari'ah though it mentions their respect to UDHR.

This study will describe and examine the 'encounter' between those three views in the policies of Indonesia concerning religious freedom. There are three general issues that will be examined throughout this essay; the concept of deity and the meaning of religion, the concept of religious freedom, and the view on religion-state relations. Those three issues will be described one after another, examining how state policies have compromised between these three views. Prior to describing and examining Indonesian policies, the universalist view, mainly stated in UDHR and ICCPR, the Islamic views, stated in the Cairo Declaration ${ }^{9}$ and in the Universal Islamic Declaration on Human Rights (UIDHR), ${ }^{10}$ and the Asian views, stated in the Bangkok Declaration and the Kuala Lumpur Declaration, will be described and commented briefly. Unfortunately, the Bangkok Declaration, which was signed by representatives of Asian states, mentions only a general statement on human rights. It does not mention human rights in details. For example, it does not throughly mention religious freedom and any statement concerning deity. Therefore, the Kuala Lumpur Declaration will be the main reference for the Asian view of this paper. It should be mentioned here that even though there is the so-called Asian Human Rights Charter initiated by non-governmental organisations as a response to the Bangkok Declaration, however I prefer not to include the charter in the discussion as the Indonesian government does not sign the charter.

${ }^{9}$ Since there is not a single view so-called Islamic view on human rights, the Cairo Declaration is chosen to represent the Islamic one because it was signed by the official representatives of the Muslim countries..

${ }^{10}$ UIDHR is initiated by the London-based Islamic Concil for Europe, a private organisation affiliated with the Muslim World League. See, http://mmm.alhewar.com/ ISLAMDECL.html. It is important to note that though the UIDHR was initiated by non governmental organisations, it will be regarded as complementary to the Cairo Declaration because most of its articles contain similar ideas with that of the Cairo Declaration. Moreover, the Quranic quotes mentioned throughout the declaration are helpful to understand the Islamic views. 


\section{B. The Concept of Deity and the Meaning of Religion}

There are several provisions related to the right to religious freedom in the UDHR, the ICCPR, together with the Declaration on the Elimination of All Forms of Intolerance and of Discrimination Based on Religion or Belief (DEAFIDBRB). However, the core provision is stated in article 18 of the UDHR, which is in turn reaffirmed and elaborated further by article 18 of the ICCPR and then by the DEAFIDBRB, especially articles 1,5 and 6 . Article 18 paragraph 1 of the ICCPR states: ${ }^{11}$

1. Everyone shall have the right to freedom of thought, conscience and religion. This right shall include freedom to have or to adopt a religion or belief of his choice, and freedom, either individually or in community with others and in public or private, to manifest his religion or belief in worship, observance, practice and teaching.

2. No one shall be subject to coercion which would impair his freedom to have or to adopt a religion or belief of his choice.

3. Freedom to manifest one's religion or beliefs may be subject only to such limitations as are prescribed by law and are necessary to protect public safety, order, health, or morals or the fundamental rights and freedom of others.

4. The States Parties to the present Covenant undertake to have respect for the liberty of parents and, when applicable, legal guardians to ensure the religious and moral education of their children in conformity with their own convictions.

In article 18 of the ICCPR, the General Comment of the Committee, which could be considered as the authoritative interpretation, states that the terms 'belief' and 'religion' are to be broadly construed. It is "not limited in its application to traditional religions or to religions and beliefs with institutional characteristics or practices analogous to those of traditional religions." ${ }^{\prime 2}$ However, what is important to note is that the words 'thought, conscience and religion' would include almost every aspects of personal conviction, such as philosophical, cultural, scientific, religious and even political aspects. The insertion of the word 'whatever'

${ }^{11}$ Article 18 of the ICCPR is quoted here, instead of article 18 of the UDHR because the former is more developed than that of the latter and it has stronger legal binding to many states.

${ }^{12}$ The General Comment on Article 18 of the Covenant (Official Records of the General Assembly, Forty-eighth Session, Supplement no. 40 [A/48/40 Part I], Annex VI) (hereafter: The General Comment), par. 2. 
in the DEAFIDBRB reflects such a notion, since this word was inserted under the request of the Eastern European states. As an implication, the words 'thought, conscience and religion' include theistic, non-theistic and also atheistic beliefs, such as agnosticism, free thought and rationalism. In the words, as Partsch suggests, it implies "all possible attitudes of the individual toward the world, toward society, and toward that which determines his fate and the destiny of the world, be it a divinity, some superior being or just reason and rationalism, or chance."13 Therefore, it is right to argue that, firstly, there is neither an exact concept of deity in the international standard nor a certain concept of religion. The scope of the word 'belief' is very wide and quite open. It is also necessary to mention that the word 'belief' is not limited to a concept related to deity.

However, the Cairo Declaration does not have a very clear-cut definition of religion either. But if this declaration is understood within the Islamic context, the concept of deity and religion implies a clearer understanding. It is stated in paragraph 9 of the preamble that:

Believing that fundamental rights and freedoms according to Islam are an integral part of the Islamic religion and that no one shall have the right as a matter of principle to abolish them either in whole or in part or to violate or ignore them in as much as they are binding divine commands, which are contained in the Revealed Books of Allah and which were sent through the last of His Prophets to complete the preceding divine messages and that safeguarding those fundamental rights and freedoms is an act of worship whereas the neglect or violation thereof is an abominable sin, and that the safeguarding of those fundamental rights and freedom is an individual responsibility of every person and a collective responsibility of the entire Ummah;

Furthermore, article 1 paragraph (b) states:

All human beings are Allah's subjects, and the most loved by Him are those who are most beneficial to His subjects, and no one has superiority over another except on the basis of piety and good deeds.

The word 'Allah' in the Islamic understanding has a very specific meaning: it means the One and Only God. The Oneness of God in the

${ }^{13}$ Cited by Martin Scheinin, "Article 18" in Gudmundur Alfredsson and Asbjǿrn Eide, The Universal Declaration of Human Rights: a Common Standard of Achievement the Hague: Martinus Nijhoff Publishers, 1999), p. 380. 
Islamic teachings is very central, and it was asserted in the 1997 Tehran Declaration mentioning 'Stressing their full adherence to tawhid, as the foundation for man's true freedom. ${ }^{, 14}$ Related to such a specific concepts of deity, Islam claims itself as the true religion, as reflected in article 10 of the Cairo Declaration that says:

Islam is the religion of true unspoiled nature. It is prohibited to exercise any form of pressure on man or to exploit his poverty or ignorance in order to force him to change his religion to another religion or to atheism.

As a consequence of such understanding, Islam considers other religions, especially religions of the Book (those who believe in one of the heavenly revealed scriptures, mainly Jewish and Christianity) as second class religions (dimmis), while the other religions, those who do not believe in one of the heavenly revealed scriptures, are considered as non-believers. ${ }^{15}$

We could compare the mentioned views with that of the Asian. As stated earlier, the Bangkok Declaration does not deal with specific rights. It merely deals with some general statements, so that it doesn't mention deity and religion. A slight concept of deity, mentioned in the preamble of Kuala Lumpur Declaration, says:

Whereas, the peoples of ASEAN recognize that all human beings are created by the Almighty, and possess fundamental rights which are universal, indivisible and inalienable;

By mentioning that 'all human beings are created by the Almighty,' the Kuala Lumpur Declaration has a specific concept of deity, though narrower than the deity concept mentioned in the UDHR and ICCPR and broader than that of Islam. Such a concept implies that the Kuala Lumpur Declaration recognises the equality of religions, but seems to reject atheism and humanism.

In the Indonesia contexts, deity and religion are clearly recognised

${ }^{14}$ The first paragraph of the preamble of the Tehran Declaration, Eighth Islamic Summit Conference, The Session of Dignity, Dialogue, Participation, Sha'aban, 1418 - December 1997. http:/ / www.oic-un.org/8/tehdec.htm.

${ }^{15}$ See Abdullahi A. An-Na'im, "Religious Minorities under Islamic Law and the Limits of Cultural Relativism,” in Human Rights Quarterly 9 (1987) 1-18. 
by the constitution. In the Preamble of the 1945 Constitution, ${ }^{16}$ the recognition of the 'religiousity' of the Indonesian is certified. Paragraph 3 of the Preamble asserts that the independence of Indonesia is regarded as a blessing of The Almighty God. This religious point of view on the existence of the state of Indonesia is not merely lip service. This recognition is indeed formulated as the first principle of Pancasila. In paragraph 4 of the same Preamble, it is written that the Indonesian state should be based on the constitution. The constitution itself is based on five basic principles: the belief in the One and Only God, justice and humanity, the unity of Indonesia, democracy guided by the inner wisdom of deliberations among representatives and the realisation of social justice for all the people of Indonesia. ${ }^{17}$

Originally Pancasila was apparently based on a broad concept of deity. In the elucidation of paragraph 4 of the Preamble of the 1945 Constitution, it is stated that 'the state is based on the One and Only God according to the principle of just and civilised humanity.' The phrase 'according to the principle of just and civilised humanity' could be interpreted as if the concept of deity ('God') should not be limited to the teaching of one particular religion. In other words, it should include many different concepts of deity. However, at present such a concept is becoming narrower, as reflected in Pedoman Penghayatan dan Pengamalan Pancasila/P4 (The Guidelines for the Internalisation and Implementation of Pancasila). ${ }^{18}$ According to P4, the first principle of Pancasila means:

The Indonesians declare their belief in and their devotion to the One and Only God, and because of it Indonesian believe in and is devoted to the One and Only God in accordance with his/her own religion and

${ }^{16}$ This is the Constitution which is currently in effect in Indonesia since Soekarno reinstated it on 5 July 1959. Between 1945-1959 there were two other constitutions which. They were the 1950 Constitution (or the Constitution of the Republic of Federal Indonesia, which consists of 197 articles) and the Provisional Constitution of 1950 (which consists of 146 articles) which were regarded by some scholars as more democratic since they were more committed to human rights.

${ }^{17}$ The English translation for this section and also for other articles in the 1945 Constitution is taken from http://inic. utexas.edu/asnic/countries/indonesia/ ConstIndonesia.html (accessed on 5 March 2001 on 11.45 AM).

${ }^{18}$ Tap. MPR no. II/MPR/1978, but it has been supressed by the decision of the People's Consultative Assembly number XVIII/MPR/1998. 
belief, based on just and civilised humanity.

Such a special recognition to the monotheistic concept of deity is reiterated in article 29 paragraph 1 of the 1945 Constitution which says, "The State shall be based upon the belief in the One and Only God." Concerning this matter, it is necessary to note that in the beginning the state does not explicitly impose a very specific meaning of the One and Only God. The BP-7 (Badan Pembinaan Pendidikan Pelaksanaan P4) ${ }^{19}$ says that, "to believe in and to be devoted to the One and Only God in accordance with their own religions and beliefs, based on just and civilised humanity." ${ }^{20}$ However, in the Provisional People's Consultative Assembly number XLI/MPRS/1968 (on the principal tasks of the Kabinet Pembangunan/ 'Development' Cabinet) article 3 stated that the first requirement for becoming a state minister is to be devoted to the One and Only God. The same requirement was also applied to the presidential and vice-presidential candidates ${ }^{21}$ and to the members of the People's Consultative Assembly. ${ }^{22}$ There is no exact reason for these requirements, but since that decree mentioned the importance to erase the influence of communism in Indonesian society, the requirements should be understood within anti-communism and atheism.

Moreover, article 156a of the penal code states that people will be brought to jail at the longest for five years those who publicly, deliberately express or act:

1. something which is in principle hostile to or abusing or staining a religion existing in Indonesia,

2. in order that somebody should not profess religion which has the One and Only God as its pivotal principle.

Paragraph 'b' above clearly highlights the importance of the specific meaning of deity in Indonesia, though in Law nr. 5/1969, the state recognises six religions, i.e., Islam, Protestantism, Roman Catholicism,

${ }^{19}$ The Institution for Training, Educating and Exercising P4. It was a presidential institution, founded in 1978, of which the main task is to socialize P4.

${ }^{20}$ Bahan Penataran, Jakarta: BP-7 Pusat, 1990, p. 28.

${ }^{21}$ The People's Consultative Assembly's decree number II/MPR/1973 on the procedure of presidential and vice-presidential election, article 1.d.

${ }^{22}$ The People's Consultative Assembly's decree number I/MPR/1983 on the statute on the people's consultative assembly, chapter III article 6.(1)a. 
Hinduism, Buddhism and Confucianism..$^{23}$ At the same time the above Law mentions that other religions such as Judaism, Zoroastrianism, Shintoism and Taoism are not prohibited. There is not an explicit statement that distinguishes these religions into 'first class' and 'second class.' However, by mentioning that the first six religions are officially recognised, they will be treated differently by the state, while the other religions are merely not prohibited to exist.

In the elucidation of the above Law it is also mentioned that religious movements which are mostly rooted in 'traditional' belief systems would be directed to a 'truthful' belief in the One and Only God. Furthermore, the 1978 Broad Outlines of State Policy, issued by People's Consultative Assembly, officially recognises that traditional religious movements are excluded from the definition of religion. They [people affiliated with those movements] need guidance in order that they do not direct themselves to adhere a new [misleading] religion (italics mine). ${ }^{24}$ This decree was of course in favour of Islam. ${ }^{25}$ However, this decision raised problems for the adherents of traditional religions/beliefs as they should choose one among the five recognised religions. Furthermore, they also should mention their preferred religion (one of fives recognised religions) on their identity card (Kartu Tanda Penduduk/KTP), otherwise they would face problems. In addition, it is necessary to note that in 1976 the Attorney General also banned Manunggal, a Javanese mysticism group, since it was considered not to believe in the One and Only God. ${ }^{26}$ Within this context, on 7-8 May 1979, in their national congress, ten Buddhist sects have declared that the One and Only God is the foundation of Buddhism in Indonesia. Similarly, the Kaharingan, which was formerly a

${ }^{23}$ During the New Order era, Confcianism, since it is regarded having close relation with Chinese culture, based on the presidential decree number 14/1967 on Chinese religion, belief and customs, was not recognized as religion. It has been abrogated by the presidential decree number 6/2000 which means that at present the celebrations of Chinese religion or customs do not need any state permission.

${ }^{24}$ The 1978 Broad Outlines of State Policy, the decree of People's Consultative Assembly number II/MPR/1978.

${ }^{25}$ See the Letter of the Minister of Religious Affairs to the Minister of Internal Affairs number B VI/5996/1990, 17 July 1980.

${ }^{26}$ The Decree of the Attorney General number KEP-006/B-2/7/1976. 
Dayak traditional religious movement, joined Hinduism. ${ }^{27}$

The above problems are of course key consequences of the blurring meaning of religion in the constitutional formulation and in its annotation. The simultaneous placement of 'religion' and 'belief' in paragraph 2 causes an ambiguity of interpretation. Religion is understood as the 'modern' beliefs which were brought by 'foreigners to Indonesia, such as Hinduism, Buddhism, Islam, Christianity and also Confucianism. ${ }^{28}$ It is contrasted with the meaning of belief (kepercayaan), which is usually understood as the traditional belief systems or indigenous religion.

\section{The View on Religious Freedom}

As mentioned earlier, the core provisions on the rights to religious freedom in the international view are stated in article 18 of the UDHR, article 18 of the ICCPR and in articles 1, 5, 6 of the DEAFIDBRB. As quoted, article 18 par. 1 mentions the contents of the rights to religious freedom, par. 2 mentions the principle of immunity, par. 3 mentions the limits, whereas par. 4 mentions the rights of parents. From these provisions, several general views can be drawn. First, the international standard emphasises the immunity from external interference on the internal, individual rights to religious freedom. Though there is change of expression from article 18 of the UDHR ('freedom to change his religion or belief') into 'to have or to adopt a religion or belief of his choice' in article 18 of the ICCPR, it is clear from the travaux préparatoires that the idea of freedom to change one's religion or belief still exists, including in the terms 'to have or to adopt.' The DEAFIDBRB also explained such notion, especially with the provision of article $8{ }^{29}$ The General

${ }^{27}$ The Letter of the Minister of Religious Affairs to the Head of Central Kalimantan Provincial Branch of Department of Religious Affairs number MA/203/1980, on 28 April 1980. For problems of the state recognition toward indegeneous beliefs see for example Rita Smith Kipp and Susan Rodgers, "Introduction: Indonesian Religions in Society," in Rita Smith Kipp and Susan Rodgers, Indonesian Religions in Transition, Tucson: The University of Arizona Press, 1989, p. 27.

${ }^{28}$ Agama, which covers a narrower range than the English term, could also be understood as "an attribute of a rich and foreign civilisation." Rita Smith Kipp and Susan Rodgers (eds.), Indonesian Religions in Transition (Tucson: The University of Arizona Press, 1989), p. 21.

${ }^{29}$ Art. 8 of the DEAFIDBRB, "Nothing in the present Declaration shall be construed as restricting or derogating from any right defined in the Universal Declaration 
Comment paragraph 5 states that it entails "the freedom to choose a religion or belief, including, inter alia, the right to replace one's current belief with another or to adopt atheistic views, as well as the right to retain one's religion or belief."

The second general idea is the relatively clear distinction between the rights in the forum internum and in the forum externum. The contents of the former can be categorised into different kinds of rights, vir, passive rights, active rights, negative rights and positive rights. Passive rights would include, inter alia, the right to have or to hold religion or belief, and to receive external information. It could be negative, such as not-to hold any belief, or be positive, such as to hold or to maintain one religion or belief. On the other side, the active rights could be distinguished into negative and positive right as well. The active-positive rights would include, inter alia, the right to look for information, to learn any belief, to choose and to adopt any religion; and the active-negative one would mean, inter alia, to argue or to reject external influence, to abandon his/ her old belief or conviction. ${ }^{30}$

Some basic contents of the rights in the forum externum are mentioned in article 6 of the DEAFIDBRB, i.e., the rights

- to worship or assemble in connection with a religion or belief, and to establish and maintain places for these purposes;

- $\quad$ to establish and maintain appropriate charitable or humanitarian institutions;

- $\quad$ to make, acquire and use to an adequate extent the necessary articles and materials related to the rites or customs of a religion or belief;

- to write, issue and disseminate relevant publications in these areas;

- $\quad$ to teach a religion or belief in places suitable for these purposes;

- $\quad$ to solicit and receive voluntary financial and other contributions from individuals and institutions;

- $\quad$ to train, appoint, elect or designate by succession appropriate leaders called for by the requirements and standards of any religion or belief;

- $\quad$ to observe days of rest and to celebrate holidays and ceremonies in accordance with the precepts of one's religion or belief;

- $\quad$ to establish and maintain communications with individuals and communities in matters of religion and belief at the national and

of Human Rights and the International Covenants on Human Rights."

${ }^{30}$ For this approach, see Michael Nowak, U.N. Covenant on Civil and Political Rights. CCPR Commentary Kehl/Strasbourg: N.P. Engel Publisher, 1993, pp. 314-319. 
international levels.

The third idea is that the rights in the forum internum, since it is private and personal, is absolute, while those in the forum internum, since it is public and related to other human beings, can be restricted. To guarantee the absolute or inviolable character of this freedom in the forum internum the ICCPR added another provision in paragraph 2 article 18 , which is repeated in verbatim by the DEAFIDBRB in paragraph 2 of article 1 as stated above. The main concern of this paragraph is to guarantee the freedom in the internal forum from any external intervention, even from one's religious institution that he/she holds. The words 'his choice', which qualify 'religion and belief', show the value of individual freedom. ${ }^{31}$ It is also to assure the right to freedom from religion, which means to protect "non-religious persons and members of religious minorities from obligatory participation in religious oaths, ceremonies and similar obligations, which are common in countries having a State church." 32

The fourth idea is that the rights to religious freedom are not unlimited, though the limits are merely applied to the rights in the forum externum. The explicit limitation for religious freedom is mentioned only in the ICCPR, which, as mentioned earlier, is repeated in verbatim in the DEAFIDBRB (article 1 paragraph 3). Article 29 of the UDHR, ${ }^{33}$ especially paragraph 2 , states only the general rules of the possibilities, due to their necessities, for the limitations of rights. The more exact provision is stated in article 18 paragraph 3 of the ICCPR:

Freedom to manifest one's religion or beliefs may be subject only to such limitations as are prescribed by law and are necessary to protect public safety, order, health, or morals or the fundamental rights and freedom of others.

This provision mentions that there are three conditions that should

${ }^{31}$ Nowak, U.N. Covenant, p. 318.

${ }^{32}$ Scheinin, "Article 18," p. 391.

${ }^{33}$ Article 29 of the UDHR: 1) In the exercise of his rights and freedom, everyone shall be subject only to such limitations as are determined by law solely for the purpose of securing due recognition and respect for the rights and freedom of others and of meeting the just requirements of morality, public order and the general welfare in a democratic society. 2) These rights and freedom may in no case be exercised contrary to the purposes and principles of the United Nations. 
be fulfilled in order to restrict the right to manifest one's religion or belief. They are: (a) to be prescribed by law, (b) to serve one of the listed purposes, and (c) to be necessary for attaining this purpose. ${ }^{34}$ Concerning this matter, the General Comment, besides underlining the importance of the above conditions, mentions three other important additional notes to consider. First, the above provision should be interpreted strictly. Second, restriction or limitation may not be imposed for the purpose of discrimination. Third, persons already subject to certain legitimate constraints, such as prisoners, may continue to enjoy their rights to manifest their religion or belief to the fullest extent compatible with the specific nature of the constraint. ${ }^{35}$ In other words, based on the above article, the limitations could be applied only under specific conditions. By mentioning two general conditions ('prescribed by law' and 'necessary to protect public safety, order, health, or morals or the fundamental rights and freedom of others'), the article suggests that the limitations may not be applied arbitrarily and must seriously consider the principle of necessity.

Finally, the issue on proselytising a religion should be taken into account as well, since it is a thorny issue although the international standard does not deal with such an issue explicitly. However, there are at least three guidelines from the international documents. First, as one form of religious manifestations, such an activity cannot be prohibited at all. Second, since it is a manifestation of religion, it can be limited as far as necessary. One of the key concept is that proselytisation can be limited or even prohibited if it uses coercion. Third, the individual freedom in the forum internum, especially to seek for information on religious matter, should be respected as well.

The above universalist views can be contrasted to the Islamic lights. However, it is surprising that the Cairo Declaration does not have an explicit article concerning the rights to religious freedom which sounds similar to that of the international documents. Rights of religious freedom are merely mentioned implicitly in some articles; article $1 \mathrm{a}^{36}$ proclaiming

${ }^{34}$ Nowak, U.N. Covenant, p. 325; 31.

${ }^{35}$ See the General Comment, par. 8.

${ }^{36}$ Article 1a of the Cairo Declaration, "All human beings form one family whose members are united by their subordination to Allah and descent from Adam. All men are equal in terms of basic human dignity and basic obligations and responsibilities, 
equality and article $18 \mathrm{a}^{37}$ mentioning the right to live securely in one's religion. It is worth noting that the articles should be understood in the terms of shari'ah as stated in article 25 that:

The Islamic shari'ab is the only source of reference for the explanation or clarification of any of the articles of this Declaration.

Therefore, the definition of religious freedom, according to the declaration, should be situated within the shari' $a$ h. In addition, it is worth noting that shari' $a b$ is a limit to the rights to religious freedom, as stated more explicitly in article 24 proclaiming :

All the rights and freedoms stipulated in this Declaration are subject to the Islamic shari'ah.

However, the so-called Islamic statement on religious freedom can be found in article XIII of the Universal Islamic Declaration on Human Rights:

Every person has the right to freedom of conscience and worship in accordance with his religious beliefs.

This article mentions explicitly only two rights, i.e., freedom of conscience and worship. The former can be regarded as the freedom in the forum internum, while the latter is in the forum externum. Prior to the article XIII, the article X, concerning rights of minorities, reaffirms the immunity of the rights in the forum internum as it mentions:

- The Qur'anic principle 'There is no compulsion in religion' shall govern the religious rights of non-Muslim minorities.

- In a Muslim country religious minorities shall have the choice to be governed in respect of their civil and personal matters by Islamic Law, or by their own laws.

Related to the rights in the forum externum, there is also guarantee for the right to participate in religious life and to free association (article $\mathrm{XIV}){ }^{38} \mathrm{It}$ is also necessary to note that the freedom of religion is

without any discrimination on the basis of race, colour, language, belief, sex, religion, political affiliation, social status or other considerations. The true religion is the guarantee for enhancing such dignity along the path to human integrity."

${ }^{37}$ Article 18a of the Cairo Declaration, "(a) Everyone shall have the right to live in security for himself, his religion, his dependents, his honour and his property."

${ }^{38}$ Article XIV: a) Every person is entitled to participate individually and collectively in the religious, social, cultural and political life of his community and to 
distinguished from the rights to freedom of belief, thought and speech, as we could observe at the article XII:

- Every person has the right to express his thoughts and beliefs so long as he remains within the limits prescribed by the Law. No one, however, is entitled to disseminate falsehood or to circulate reports which may outrage public decency, or to indulge in slander, innuendo or to cast defamatory aspersions on other persons.

- Pursuit of knowledge and search after truth is not only a right but a duty of every Muslim.

- It is the right and duty of every Muslim to protest and strive (within the limits set out by the Law) against oppression even if it involves challenging the highest authority in the state.

- There shall be no bar on the dissemination of information provided it does not endanger the security of the society or the state and is confined within the limits imposed by the Law.

- No one shall hold in contempt or ridicule the religious beliefs of others or incite public hostility against them; respect for the religious feelings of others is obligatory on all Muslims.

However, we can not find any explicit provision concerning proselytisation. Since both the Cairo Declaration and the UIDHR mention shari'ah as the only source, it is clear that there is only one side of proselytising religion, i.e., non-Muslims becoming Muslim, not the other way around.

Comparing the two forementioned views, the Kuala Lumpur Declaration recognises the equality of all people. Everyone has a right to live in dignity. ${ }^{39}$ Related to such recognition, it guarantees rights to religious freedom as stated in article 8:

Everyone has the right to freedom of thought, opinion, conscience and religion, these rights include freedom of teaching, practice, worship and observance, both in private and public, individually or in community

establish institutions and agencies meant to enjoin what is right (ma'rüf) and to prevent what is wrong (munkar). b) Every person is entitled to strive for the establishment of institutions where under an enjoyment of these rights would be made possible. Collectively, the community is obliged to establish conditions so as to allow its members full development of their personalities.

${ }^{39}$ Article 2 of the Kuala Lumpur Declaration mentions "All human beings, without distinction as to race, colour, sex, language, religion, nationality, ethnic origin, family or social status, or personal convictions have the right to live in dignity and to enjoy the fruits of development and should, on their part, contribute to and participate in it." 
with others.

This provision is similar with that of the UDHR and of the ICCPR. Several rights, both in the forum internum and in the forum externum, are mentioned. Nevertheless, the terms 'teaching, practice, worship and observance,' as those of the UDHR and of the ICCPR, include very broad contents. The only difference is that it does not mention the right to change one's religion. However, it does not mean that the right is not guaranteed at all as there is no clear prohibition to change one's religion mentioned.

However, differing from the ICCPR, the Kuala Lumpur Declaration does not mention any limit for the above rights. The only hint for the limitation is rights of others and also one's own duties to the community as article 1 of the declaration states:

All human beings, individually and collectively, have a responsibility to participate in their total development, taking in account the need for full respect of their human rights as well as their duties to the community. Freedom, progress and national stability are promoted by balance between the rights of the individual and those of the community.

In addition, the importance of the balance between the individual and the community, between rights and duties or obligations, is stated in paragraph 4 of the preamble. ${ }^{40}$ Besides this, paragraph 5 mentions the importance of historical-cultural context for the applications of that declaration. ${ }^{41}$

The Indonesian views, as mentioned in the Preamble of the 1945 Constitution, demonstrate that the religion as the basis of the state, in addition it guarantees the religious freedom of the people as mentioned in article 29 of the 1945 Constitution:

- The State shall be based upon the belief in the One and Only God.

- The State guarantees the freedom to adhere one's own religion and to worship for all inhabitants according to his/her own religion or belief.

40 "Whereas, the peoples of ASEAN recognise that human rights have two mutually balancing aspects ; those with respect to rights and freedom of the individual, and those which stipulate obligations of the individuals to society and State."

41 "Whereas, the peoples of ASEAN accept that human rights exist in a dynamic and evolving context and that each country has inherent historical experiences, and changing economic, social, political and cultural realities and value systems(s) which chould be taken into account." 
In the Annotations ${ }^{42}$ to the Constitution, it is only stated for paragraph 1 of article 29 that "this section emphasises the belief of the Indonesian people in the One and Only God" 43 and there is no further elucidation on paragraph 2, consequently this later article is ambiguous.

Based on paragraph 1 of the above article the Indonesian state obliges, though indirectly, its citizens to embrace one out of the five recognised religions and to mention the embraced-religion on the national identity card. This obligation has a great impact, both in the national and the personal sphere. In the national sphere, this obligation gives statistical data, which in turn, could be used by some politicians and even by the government to legitimise their policies. ${ }^{44}$ In the personal sphere, not mentioning a particular religion would cause problems for the citizens. For example, it would be difficult for them to become civil servant, ${ }^{45}$ and police/military officers, ${ }^{46}$ including to register their marriage and to have death-funeral ceremony. ${ }^{47}$

In paragraph 2 of article 29 above, the state has obligation to 'guarantee' (menjamin) the two for its citizen, i.e., to embrace one's religion and to worship. The article is indeed the only constitutional base for the rights to religious freedom of the citizens, but there is no explicit statement on the right to change one's religion. The absence of such a

${ }^{42}$ Other scholar prefers to use the word 'Elucidation' for the English translation Penjelasan' (tentang Undang-undang Dasar Negara Indonesia) since it is part of the Constitution explaining the articles. See Lubis, op.cit., p. 81.

${ }^{43}$ Penjelasan tentang Undang-undang Dasar Negara Indonesia, pasal 29 ayat 1, "Ayat ini menyatakan kepercayaan bangsa Indonesia terhadap Tuhan Yang Maha Esa."

${ }^{44}$ However, President Soeharto at the beginning of his power mentioned that the distinction between majority and minority should not become a problem. See his speech in front of the Gotong Rojong House of Representatives, 16 August 1967.

${ }^{45}$ Law number 2/1989 on national education, article 28 paragraph 2, and it is asserted in the governmental regulation number 38/1992 (signed on 17 July 1992) article 9 paragraph $1(2)$.

${ }^{46}$ Law number 1/1998 on 'Perubahan atas UU no. 20/82 tentang Ketentuan-ketentuan Pokok Pertahanan Keamanan Negara Republik Indonesia' (the Change on Law number 20/82 on the Principle Stipulations of the Defense of Security of Republic of Indonesia) article 10 paragraph 2 .

${ }^{47}$ It is stated in the Law 1/1974 (signed on 2 January 1974) article 1 that a marriage will be officially valid before the state if it is valid according to his/her religion. See the Letter of Minister of Religious Affairs to the Minister of Internal Affairs number B VI/5996/1990, 17 July 1980. 
statement does not mean that the state does not guarantee such a right, since in fact the citizens are relatively free on such a matter. Furthremore, the decree of the Minister of Religious Affairs no. 70/1978 mentions that the state does not interfere with those who voluntarily change their religion based on their own will and conscience.

Moreover, the state does not prohibit people to gather information about other religions as he/she performs on their own free will. Related to this matter, in spite of regulating -if not to mention prohibiting'missionary activity', the above ministerial regulation rules the issue ambigously. It mentions that religious propagation activities should not be addressed to those who have already professed a particular religion whereas at the same time the freedom of gaing information is guaranteed

This ambigous attitude is exarcebated by the facts that some state regulations on certain religion delivered impacts to other religious adherents -to mention national impacts-, such as the state's regulation of the national holidays based on particular religious days of celebration. Another example of state's regulations based on a particular religious teaching, but with a national impact, is the state's regulation on the prohibition of gambling ${ }^{48}$ and the issue of public morality. This later issue could be seen in articles 3 and 4 of Law number 24/1997 (signed on 29 September 1997) on broadcasting which mention that one of the principles and the goal of broadcasting is the development of faith and of devotion to the One and Only God. Furtheremore, this regulation rules the regulation on television broadcasting ${ }^{49}$ and legitimises the existence of Lembaga Sensor Film/LSF (the Institution for Film Censorship)..$^{50}$ In the article 15 of Law number 24/1997, it is mentioned that religious programs should be included in the television program, in balance with others. Consequently, every Indonesian television station must broadcast a religious program (sometimes it is known as mimbar agama or religious podium) for every religion. Pertaining to the LSF, the state appointed religious leaders as its members, showing that the state appreciation

${ }^{48}$ The governmental regulation number $9 / 1981$ (signed on 28 March 1981) on the implementation of the control on gambling is based on Law number 7/1974 on controlling gambling.

49 The Decree of the Minister of Information number 111/KEP/MENPEN/ 1990 on Television Broadcasting in Indonesia.

${ }^{50}$ See Law number 8/1992 on Film, article 34 paragraphs 1 and 3. 
towards religious values in building public morality. In addition, on behalf of the concern for [religiously inspired] public morality, the Attorney General also prohibited the circulation of printed matters related to the Children of God movement. ${ }^{51}$ By decree the Minister of Finance has also removed the taxes for importing religious books as it is deemed as contributing to national mental health. ${ }^{52}$

Nevertheless, there were also several regulations that guarantee religious freedom in the personal sphere, such as the right of prisoners to worship ${ }^{53}$ and to have spiritual assistance, ${ }^{54}$ in addition to rights of spiritual assistance for the military officers. Concerning the spiritual assistance of the military, the state has established its own institution, viz., Pusat Bimbingan Mental/Pusbintal (the Centre for Mental Guidance), ${ }^{55}$ which cooperates with religious institutions for its services and gains financial supports from the government. ${ }^{56}$ Another instance is right for each citizen to be exempt from military service on religious grounds as mentioned on article 3 of Law number $1 / 1998 .{ }^{57}$

Concerning the limits to the rights to religious freedom, the nature of the Indonesia constitution itself however should be taken into account at first. It is worth noting that the 1945 Constitution contains only 37 articles and rules general principles as mentioned in the Annotations:

It is adequate that the constitution only contains the fundamental

${ }^{51}$ The Decree of the Attorney General number KEP-058/J.A/3/1984, signed on 12 March 1984.

52 The Decree of the Minister of Finance number 497/KM.1/1979, signed on 28 June 1979.

${ }^{53}$ The Government Regulation number 32/1999 (signed at 19 May 1999) on the Requirements and Procedure of Realization of the Rights of Those who are in the Correctional Institution article 2. Since it was issued in 1999, it actually means that it does not belong to the New Order era.

${ }^{54}$ The Government Regulation number 32/1999 article 6.

${ }^{55}$ For the army, for example, see the decree of the Army Head Officer number Skep/1111/XI/1977 (signed on 22 November 1977) as a realization of the previous decree number Skep/1246/IX/1976 (signed on 20 September 1976).

${ }^{56}$ There is also a salary for the titular military, see for example the circular letter of the Minister of Defense and Security/the Armed Forces Chief Commander number SE/21/IX/1981 (signed on 14 September 1981).

${ }^{57}$ Article 3, "Warga Negara sebagaimana dimaksud dalam ayat (1) dapat dibebaskan dari kewajiban dinas keprajuritan karena (b.) mereka yang menjabat suatu jabatan agama dan/ atau menganut agama yang ajarannya tidak membolebkannya." 
provisions and guidelines as directives for the government and other state institutions to conduct state affairs and create public welfare. In particular for a new and young country, such a basic law is best to contain the basic provisions only while the operational procedures can be accommodated in laws which are easier to make, amend and repeal. Hence the system in which the constitution is drafted.

Prior to the above, it is written that:

The Constitution of the country is only a part of its basic law. It is the written part. In addition, there is the unwritten part of the basic law which comprises principal regulations that grow and are preserved in the conduct of state affairs.

The both mentioned statements should be understood within the context of the 'transition' of young Indonesian state in which the 1945 Constitution was drafted as mentioned in the last part of the Constitution. However, we could argue that the fundamental ideas of 1945 Constitution does not cover limitation, despite it gives general principles. Should there be limitation, it is mentioned in the lower regulations, such as in the penal code and the regulation regarding religious mission which are aimed at maintaining public order. The penal code mentions that the right to manifest one's religion is limited when public expression could cause hatred, enmity and humiliation. ${ }^{58}$ The main concern for the regulation is to maintain social stability and public order. Concerning social stability and public order on religious affairs, the decree of the Minister of Religious Affairs nr. 70/1978 guidelines for the propagation of religion more spesifically mentions that national stability and religious harmony are two important 'frames' for the rights to religious freedom. Religious harmony is indeed one of the most important conditions for maintaining national unity, while national stability is the condition for achieving national development.

\section{The View on Religion-State Relation}

It is noteworthy that the international standards on the right to religious freedom do not provide the model of religion-state relation. The international instruments on human rights merely provide minimum principles and frameworks that could be followed, which in a certain

${ }^{58}$ See articles 156 and 156 a of the penal code. 
sense could also be modified to different contexts. The perspective of these international instruments are that of a plural society in which the individuals, with their own conscience and belief, exist. The state is considered a neutral party, both politically and religiously, within that society. Based on this perspective, and within the frameworks of the right to religious freedom, the Human Rights Committee urges that these principles not be impaired within any form or model of the state-religion relation as the following mentioning:

The fact that a religion is recognised as a state religion or that it is established as official or traditional or that its followers comprise the majority of the population, shall not result in any impairment of the enjoyment of any of the rights under the Covenant, including articles 18 and 27, nor in any discrimination against adherents of other religions or non-believers. In particular, certain measures discriminating against the latter, such as measures restricting eligibility for government service to members of the predominant religion or giving economic privileges to the or imposing special restrictions on the practice of other faiths, are not in accordance with the prohibition of discrimination based on religion or belief and the guarantee of equal protection under article $26 .{ }^{59}$

The just mentioned statement implies the important two. Firstly, it implicitly recognises all forms or models of the state-religion relation as far as it does not endanger the right to religious freedom for adherents of one or another religion and for non-believers. ${ }^{60}$ Therefore, the state regardless their forms and models of state-religion relation is obliged to guarantee the religious freedom of its citizens. Secondly, it also warns the state with an official religion not to disturb rights of religious minority to perform their religous lives as also mentioned in the report of the Special Rapporteur on 30 December $1996 .{ }^{61}$

It is important to underline that the above recommendations do not oppose the existence of an (official) established religion within a

${ }^{59}$ The General Comment, par. 9.

${ }^{60}$ In the history of human beings, there were several models of the state-religion relation, such as theocracy, caesaropapism, jurisdictionalism, concordation tradition and the Old-French Napoleonic tradition. In the modern era, besides the existence of some traditional models such as in some Islamic states, there are many models as well, such as the established Church-state model of England, the French laicité model, the United states' 'pure' separation, the state financing system of Belgium, etc.

${ }^{61} \mathrm{E} / \mathrm{CN} .4 / 1997 / 91$. 
state, but those two recommendations deliver an alarming potential dangers within such form of state-religion relation. In other words, the Special Rapporteur has recommended a circumstance that is more conducive to guarantee the rights of religious freedom. It would mean that, among many forms or models of the state-religion relations, the preference is a separation of those two entities, where the state stands as a neutral party. The neutrality of the state would be important since it could not be assumed that merely the rigid separation of religions and the state would bring more religious freedom. In some states, such rigid separation could bring a low religious freedom, or even hostility and persecution of religions.

As with the international standards, there is no explicit statement concerning the religion-state relation in both the Cairo Declaration and in the UIDHR. However, such a relation can be read from, first, the language they use in those two declarations and second, in the state's obligations expressed in the declarations. From the language they use, there are many theological expressions together with political statements. In the preamble of the Cairo Declarations there are some theological terms such as vicegerent of Allah, divine commands, Revealed Books of Allah, the last of His Prophet, shari'ah and abominable sin. There is also a longer theological expression stated in article $1 \mathrm{~b}$ :

All human beings are Allah's subjects, and the most loved by Him are those who are most beneficial to His subjects, and no one has superiority over another except on the basis of piety and good deeds.

The more-or-less similar expressions are also available as well in the UIDHR. These theological expressions, used in a political document, mean that there is a very close relation between religion and state. Further, those expressions reflect the understanding that Islam is both a religious entity and also a political entity. Such a view is expressed in paragraph 7 of the preamble:

Reaffirming the civilising and historical role of the Islamic umma which Allah made as the best community and which gave humanity a universal and well-balanced civilisation, in which harmony is established between hereunder and the hereafter, knowledge is combined with faith, and to fulfill the expectations from this community to guide all humanity which is confused because of different and conflicting beliefs and ideologies 
and to provide solutions for all chronic problems of this materialistic civilisation.

The (very) close relation between religion and state in the Islamic view can be seen from the obligations of the state to guarantee the rights of people which are deemed as based on the Law of Allah. ${ }^{62}$ There are many explicit statements in the Cairo Declaration concerning these obligations, but the UIDHR is more explicit by stating at the foreword (paragraph 3) that:

Human rights in Islam are an integral part of the overall Islamic order and it is obligatory on all Muslim governments and organs of society to implement them in letter and in spirit within the framework of that order.

In addition, this view is further reflected in the expression used in the preamble of the UIDHR paragraph $6 \mathrm{~g} \mathrm{nr}$ vii that 'all worldly power shall be considered as a sacred trust, to be exercised within the limits prescribed by the Law and in a manner approved by it, and with due regard for the priorities fixed by it.' In short, in the Islamic view, there is not a separation between religion and state.

Along with the two mentioned views, the Bangkok Declaration and the Kuala Lumpur Declaration do not touch upon the issue of religion and state relation. However, both declarations explicitly mention the general obligations of the state to protect and as far as possible to promote human rights. Part III (articles 11-22) of the Kuala Lumpur Declaration is dedicated to the basic rights and duties of citizens and states, though there is no specific obligation of the state concerning the rights to religious freedom. It means that the Kuala Lumpur Declaration is neutral concerning the issue of religion-state relation, in spite it underlines the importance of religion among states of ASEAN, as expressed in the invocation of 'the Almighty' in the preamble.

As with the Kuala Lumpur Declaration, the Bangkok Declaration takes a neutral position concerning the issue of religion-state relation. Though it does not recommend the separation between the religion and state, but neither does it prefer a close relationship between the two. The emphasis on cultural diversity, as explicitly mentioned in the preamble paragraph 2, means that it respects any kind of relation depending each state's socio-cultural context.

${ }^{62}$ See paragraph 2 of the foreword of the UIDHR. 
Let's look closer to Indonesia concerning the religion-state relationship. As mentioned in the beginning of this work, Indonesia is neither a confessional state nor secular ones, but 'in between' the two models of religion-state relationship. Indonesia is the 'third way' between the confessional model such as in the Islamic state and the secular state such as a state with a strict separation between state and religion. However, this 'third-way' does not generate neutrality in religious affairs as the government establish Department of Religious Affairs. It is a ministry sui generis in which the state specifically deals with the religious matters of its citizens. The establishment of the ministry was proposed by some prominent Islamic leaders, such as M. Saleh Suaidi, M. Natsir, K.H.A. Wahid Hasjim, H. Agus Salim and K.H.A. Mas Mansur, to the Komite Nasional Indonesia Pusat/KNIP (the Central Indonesian National Committee) in the first years of the Indonesia independence. The establishment of the ministriy could be seen as a compromise between Indonesian elites who preferred an Islamic state and who preferred a secular one. ${ }^{63}$

However, the ministry is far from being neutral as, in 1967, the Minister of Religious Affairs, K.H. Achmad Dachlan, issued a decree number 56/1967 mentioning that one of the principal tasks of the Department of Religious Affairs is to realise the Jakarta Charter in its relation to the 1945 Constitution. This preferential treatment of Islam in the Department of Religious Affairs is also reflected in the composition of this Department. Beside the fact that there is an unofficial rule that the minister should be a Muslim, there is an additional directorate for Islam, the so-called Direktorat Jendral Pembinaan Kelembagaan Agama Islam (General Directorate for Islamic Institutions). ${ }^{64}$ Moreover, there is also a special bureau in this department which deals with the affairs of the hajj pilgrimage. ${ }^{65}$

${ }^{63}$ For a short description of the history of the Department of Religious Affairs, see Departemen Agama R.I, Amal Bakti Departemen Agama R.I., 3 Januari 1946-3 Januari 1987, Eksistensi dan Derap Langkahnya, Jakarta: Departemen Agama R.I., 1987, pp. 10-5.

${ }^{64}$ Established in 1978, based on the presidential decree number 30/1978.

${ }^{65}$ This establishment was based on the governmental decision to take over the affair of the haij pilgrimage (the presidential decree number 22/1969, followed by the presidential instruction number 6/1969). 
However, concerning the Department of Religious Affairs, it is necessary to note that it does not merely serve Islam. As indicated in its name, the Department deals with the state's support of religions, especially of the five recognised ones. The number of the directorates of this Department is apparently based on the statistical number of the religious adherents, ${ }^{66}$ so that Buddhism and Hinduism, since there are but a few adherents, are under one directorate, while Protestants and Catholics have their own directorate and Islam has extra directorates.

\section{E. Conclusion}

Before drawing several conclusions, it is necessary to mention once again that Indonesia has signed several international documents on human rights. At the international level, though Indonesia has not ratified the ICCPR, it has been morally bound by the UDHR because Indonesia joined the UN. At the regional level, Indonesia has signed both the Kuala Lumpur Declaration and the Bangkok Declaration. Indonesia, as an active member of OIC, also signed the Cairo Declaration. Since those documents have some differences regarding the views on the rights to religious freedom, in this concluding section, the Indonesian view will be given a particular attention.

First, concerning the concept of deity and religion, the Indonesian concept is much narrower than that of the international standard but wider than that of Islam. The emphasis on the monotheistic character of deity, as expressed in the term 'the One and Only God,' is clearly influenced by Islam. On the concept of religion, Indonesia has used Islamic parameters in determining religions. That is why Indonesia rejects atheism and does not even recognise the traditional religious movements as religion. However, on the concept of religion, Indonesia does not follow Islamic teaching strictly, since it recognises Hinduism and Buddhism as well.

Second, concerning the contents of the rights to religious freedom, the Indonesia constitution guarantees only two rights: to embrace one's religion and to worship. However, these two rights are interpreted widely so that their scope includes many, from the right to change one's religion

${ }^{66}$ As reflected in article 15 paragraphs 1,2,3 of decree of Minister of Religious Affairs number 36/1972. 
to manifest it in public life. Briefly speaking, the contents of the rights to religious freedom are similar with that of the international standard. In this case, there is a slight difference with that of Islam. However, the influence of Islam is reflected in the state's promotion of several rights and also in the limitations set by the state. There are two kinds of state promotion, i.e., through state regulations and through financial supports. These two kinds of promotional activities clearly demonstrate that Islam receives special treatment by the state. The influence of Islam in the limitations of the rights to religious freedom is reflected in the limitation to propagation of religion. However, since the state also emphasises the importance of national stability and religious harmony, it can be said that the so-called Asian view on human rights, which emphasises the cultural relativity, as reflected in the Kuala Lumpur Declaration and the Bangkok Declaration, has more influence.

Third, concerning the relationship between religion and state, Indonesia tends to have a close relation between the two. Besides giving financial supports for religious activities, in certain cases the state even intervenes the private affairs of each religion, especially in Islamic affairs. Such a model is clearly closer to the Islamic model than to the so-called 'universalist' model, which prefers the separation between state and religion. Finally it can be concluded that in general the Islamic view on religious freedom has greatly influenced the Indonesian view. Concerning this influence, it can also be said that the influence of Islam is growing through lower level government regulations, especially on the ministerial level, rather than in higher level regulation, such as the constitution. Such a fact, on the one hand, is due to the fact that Indonesia has not yet ratified the ICCPR, while on the other hand it is caused by active Islamic political movements in Indonesia. In addition, it also reflects the weakness of the Indonesian legal system, especially with regards to some inconsistencies in the hierarchical legal order. 
Declarations and the Indonesian Constitution on Religious Freedom

\section{BIBLIOGRAPHY}

Scheinin, Martin, "Article 18" in Gudmundur Alfredsson and Asbjǿrn Eide, The Universal Declaration of Human Rights: a Common Standard of Achievement, the Hague: Martinus Nijhoff Publishers, 1999.

Alatas, Ali, "An Indonesian View on Human Rights," in Barend van der Heijden and Bahia Tahzib-Lie, Reflections on the Universal Declaration of Human Rights. A Fiftieth Anniversary Anthology, The Hague: Martinus Nijhoff Publishers, 1998.

An-Na'im, Abdullahi A., "Religious Minorities under Islamic Law and the Limits of Cultural Relativism," in Human Rights Quarterly 9, 1987. BP-7, Bahan Penataran, Jakarta: BP-7 Pusat, 1990, p. 28.

Departemen Agama R.I, Amal Bakti Departemen Agama R.I., 3 Januari 1946-3 Januari 1987, Eksistensi dan Derap Langkahnya, Jakarta: Departemen Agama R.I., 1987, pp. 10-15.

Kipp, Rita Smith and Susan Rodgers (eds.), Indonesian Religions in Transition, Tucson: The University of Arizona Press.

Law number 1/1998 on 'Perubahan atas UU no. 20/82 tentang Ketentuanketentuan Pokok Pertahanan Keamanan Negara Republik Indonesia’ Law number 2/1989 on national education.

Lubis, Todung Mulya, In Search of Human Rights, Jakarta: Gramedia Pustaka Utama and SPES Foundation, 1993.

Nowak, Michael, U.N. Covenant on Civil and Political Rights. CCPR Commentary Kehl/Strasbourg: N.P. Engel Publisher, 1993.

Thaher, H. Tarmizi, Kebijaksanaan dan Strategi Pemerintah dalam Pembinaan Umat Beragama, a paper presented on a one day seminar on religion and national development, organized by ICMI Jakarta branch on 9 October 1993.

The 1978 Broad Outlines of State Policy, the decree of People's Consultative Assembly number II/MPR/1978.

The circular letter of the Minister of Defense and Security/the Armed Forces Chief Commander number SE/21/IX/1981 (signed on 14 September 1981).

The decree of the Army Head Officer number Skep/1111/XI/1977. 
The Decree of the Attorney General number KEP-006/B-2/7/1976.

The Decree of the Attorney General number KEP-058/J.A/3/1984, signed on 12 March 1984.

The Decree of the Attorney General number KEP-129/A/12/1976.

The Decree of the High Attorney of North Sulawesi number KEP.2/ K4.11.4.1/1/74.

The Decree of the Minister of Finance number 497/KM.1/1979, signed on 28 June 1979.

The Decree of the Minister of Health number 226/MEN.KES/SK/ VI/1979.

The Decree of the Minister of Information number 111/KEP/ MENPEN/ 1990 on Television Broadcasting in Indonesia.

The General Comment on Article 18 of the Covenant (Official Records of the General Assembly, Forty-eighth Session, Supplement no. 40 [A/48/40 Part I], Annex VI) (hereafter: The General Comment), par. 2.

The Government Regulation number 32/1999 (signed at 19 May 1999) on the Requirements and Procedure of Realization of the Rights of Those who are in the Correctional Institution.

The Government Regulation number 32/1999.

the Letter of Minister of Religious Affairs to the Minister of Internal Affairs number B VI/5996/1990, 17 July 1980.

The Letter of the Minister of Religious Affairs to the Head of Central Kalimantan Provincial Branch of Department of Religious Affairs number MA/203/1980, on 28 April 1980.

The Letter of the Minister of Religious Affairs to the Minister of Internal Affairs number B VI/5996/1990, 17 July 1980.

The People's Consultative Assembly's decree number I/MPR/1983 on the statute on the people's consultative assembly.

The People's Consultative Assembly's decree number II/MPR/1973 on the procedure of presidential and vice-presidential election.

The speech of President Soeharto at the celebration of Nyepi (Hindu celebration), 9 April 1992. 
Declarations and the Indonesian Constitution on Religious Freedom

The speech of President Soeharto at the opening ceremony of the workmeeting of the Department of Religious Affairs, 28 March 1989.

The speech of President Soeharto in the opening ceremony of the 9th Grand Synod of Indonesian Council of Churches, 19 July 1984.

The speech of the Minister of Religious Affairs in the opening ceremony of the 10th Grand Synod of the Indonesian Council of Churches, 21 October 1984.

The Tehran Declaration, Eighth Islamic Summit Conference, The Session of Dignity, Dialogue, Participation, Sha'aban, 1418 - December 1997. http://www.oic-un.org/8/tehdec.htm. 
Alexius Andang L. Binawan 